\title{
Kontribusi Corporate Social Responsibility bagi Penguatan Kohesi Sosial Masyarakat: Studi Kasus Perusahaan Asing di Bogor
}

\section{Tantan Hermansah}

Fakultas Ilmu Dakwah dan Ilmu Komunikasi

Universitas Islam Negeri Syarif Hidayatullah Jakarta, Indonesia

Email: tantanhermansah@yahoo.com

\section{Muhtadi}

Fakultas Ilmu Dakwah dan Ilmu Komunikasi

Universitas Islam Negeri Syarif Hidayatullah Jakarta, Indonesia

Email: muhtadi_4@yahoo.com

\begin{abstract}
Abstrak
Corporate social responsibility merupakan bentuk tanggung jawab sosial yang diembankan pemerintah kepada perusahaan-perusahaan yang beroperasi di Indonesia. Banyak program CSR ini-langsung atau tidak-berdampak kepada pengembangan masyarakat. Dengan menggunakan metode observasi pada studi kasus CSR yang dilakukan oleh sebuah perusahaan di Kota Bogor, studi ini menemukan bahwa: (1) CSR menjadi instrument perusahaan yang berdampak sosial-ekonomi kepada masyarakat; (2) Secara praktis bentuk CSR bisa berbeda-beda tergantung kondisi lapangan. Kemampuan memvariansikan bentuk ini justru berimplikasi kepada keberlanjutan dari perusahaan tersebut; (3) Meski ada di lingkungan warga yang mayoritas beragama Islam, tetapi dampak langsung CSR pada masyarakat Islam di sekitar perusahaan ternyata tidak tampak menonjol, atau malah terkesan biasa-biasa saja.
\end{abstract}

Kata Kunci: Corporate Social Responsibility, Pengembangan Masyarakat, UU, Perseroan Terbatas

Studi yang menyimpulkan bahwa Corporate Social Responsibility (CSR) berkontribusi kepada pengembangan masyarakat itu sudah cukup banyak di Indonesia. CSR sepertinya semakin mendapat tempat dalam diskusi akademik apalagi pemangku kebijakan di Indonesia (Achda, 2006). Hal ini terjadi antara karena meningkatnya kesadaran dari pemerintah akan pentingnya sebuah perusahaan memikul tanggungjawab sosial-ekonomi-ekologi di (minimal) lingkungan sekitarnya. Kasus Lumpur Lapindo di Sidoarjo yang mengorbankan 
Tantan Hermansah dan Muhtadi Kontribusi Corporate Social Responsibility bagi Penguatan Kohesi Sosial Masyarakat:

Studi Kasus Perusahaan Asing di Bogor

ribuan orang yang tidak ada hubungannya dengan perusahaan, merupakan salah satu contoh betapa pentingnya kehadiran CSR dalam sistem bisnis di Indonesia.

Studi ini, meski diletakkan dalam kerangka CSR, melihat pengembangan masyarakat dalam aspek yang lebih sosiologis, yakni terjadi pengembangan masyarakat secara alamiah dan dikaitkan dengan peran CSR dalam proses perubahannya. Maka dari itu, berbeda dengan kebanyakan studi yang melihat aspek perusahaan yang mengeluarkan CSR sebagai subyek, studi ini juga memosisikannya sebagai obyek. Sebab, sejak awal studi ini melihat dan mendalami apa yang terjadi, berlaku, dan berlangsung di masyarakat.

Oleh karena itu, ketika harian Seputar Indonesia atau yang lazim disingkat Sindo meluncurkan malam apresiasi Corporate Social Responsibility (CSR) Award 2013 di Ballroom Hotel Ritz Charlton, Lingkar Mega Kuningan, Jakarta, Juni (24/6/2013), dari 27 perusahaan yang dirilis ternyata tidak tercantum nama perusahaan asing yang menjadi obyek tidak langsung kajian ini. Padahal perusahaan yang berdiri sejak tahun 1935 diatas lahan seluas $172.000 \mathrm{~m} 2$ yang hijau dan asri di kota Bogor, seharusnya bisa mendapatkan prestasi tersebut jika dilihat dari kebertahanannya dalam lingkungan dan sistem politik industrial yang ada di Indonesia.

Sebagai perusahaan dengan usia tertua untuk produksi dan manufaktur ban di Indonesia, perusahaan ini telah mendapatkan beragam apresiasi, antara lain: (1) Sertifikasi ISO 9002 (1994), sertifikasi ISO 14001, dan pada tahun 2006 meraih ISO/TS 16949:2002; Penghargaan tertinggi Kalpaltaru untuk kategori pembina lingkungan; (3) meraih status Superbrand pada tahun 2003, yang merupakan satusatunya perusahaan ban yang meraih penghargaan ini; (4) Dua penghargaan dari Toyota, yaitu Quality Target And Delivery dan Zero Defect achievement (2004).

Sementara dalam laporan resmi yang dikeluarkannya, perusahaan ini sama dengan perusahaan lainnya diharuskan mengeluarkan kewajiban berderma kepada lingkungan sebagai bagian dari kedermawanan perusahaan terhadap masyarakat. Kegiatan ini lazim disebut dengan istilah CSR atau corporate social responsibility. Ketika pemangku kepentingan menerjemahkannya dalam Bahasa Indonesia, CSR kemudian dialibahasakan menjadi Tanggung Jawab Sosial Perusahaan atau Tanggung Jawab Sosial Lingkungan. Namun demikian, karena CSR lebih dulu dikenal publik dan pemangku kepentingan, meski pengindonesiaan sudah terjadi, tetapi istilah CSR tetap saja lebih dikenal.

Studi ini menggunakan pendekatan kualitatif yang dibangun oleh Guba (2002) dan community developmentnya Jim Ife, dengan strategi studi kasus. 
Pendekatan ini dipergunakan karena dianggap memadai untuk melihat bagaimana kontribusi CSR dalam pengembangan masyarakat.

\section{Kerangka Teori}

Secara konseptual maupun praktik, CSR merupakan bentuk tanggung jawab nyata dari perusahaan yang dituntut Negara melalui Undang-undang kepada masyarakat. Bahkan dengan pendekatan yang tepat CSR bisa memberikan kontribusi positif kepada perusahaan secara ekonomi, sosial, maupun lingkungan (ekologis). Dalam ruang lingkup CSR posisi masyarakat sangat kuat. Adapun masyarakat yang dimaksud terbagi menjadi masyarakat yang langsung bersentuhan dengan lingkungan fisik perusahaan, yakni masyarakat sekitar, dan masyarakat yang tidak bersentuhan langsung, namun terkena dampak. Selain itu, kategorisasi masyarakat juga harus diperdalam yaitu, masyarakat umum yang mencakup keseluruhan strata dan lapisan masyarakat, tetapi juga masyarakat berdasarkan kategori penganut agama.

CSR dalam kerangka regulasi di Indonesia berkaitan dengan persoalan investasi perusahaan. Seperti ditegaskan dalam UU No. 25 Tahun 2007 tentang penanaman modal, bahwa untuk mempercepat pembangunan ekonomi nasional dan mewujudkan kedaulatan politik dan ekonomi Indonesia diperlukan peningkatan penanaman modal untuk mengolah potensi ekonomi menjadi kekuatan ekonomi riil dengan menggunakan modal yang berasal, baik dari dalam negeri maupun dari luar negeri. Selanjutnya, dijelaskan pula bahwa dalam menghadapi perubahan perekonomian global dan keikutsertaan Indonesia dalam berbagai kerja sama internasional perlu diciptakan iklim penanaman modal yang kondusif, promotif, memberikan kepastian hukum, keadilan, dan efisien dengan tetap memperhatikan kepentingan ekonomi nasional.

Kemudian dalam regulasi lain yakni dalam UU No. 40 tentang Perseroan Terbatas, pemerintah telah mewajibkan perusahaan untuk memiliki tanggung jawab terhadap permasalahan sosial dan lingkungan dalam bentuk Corporate Social Responsibility (CSR). Para pakar telah bersepakat bahwa jika dilihat dari perspektif sosial dan politik, CSR merupakan instrumen dalam mewujudkan suatu bentuk relasi multipihak, khususnya antara pemerintah, swasta, dan masyarakat sipil. Selain itu, CSR juga dipertimbangkan sebagai strategi manajemen yang efisien bagi perusahaan untuk mempromosikan kecederungan sosial baru dalam masyarakat melalui sejumlah aktivitas baik yang bersifat jangka pendek maupun model pembangunan sosial (social development) jangka panjang. 
Tanggung jawab ini selain merupakan komitmen perusahaan untuk berperan serta dalam pembangunan ekonomi yang berkelanjutan juga diharapkan dapat meningkatkan kualitas kehidupan dan lingkungan yang bermanfaat, baik bagi perusahaan sendiri, lingkungan, komunitas setempat, maupun masyarakat pada umumnya. Pandangan ini dilandasi suatu pemikiran bahwa jika perusahaan ingin bertahan lama, maka lingkungan sosial tempat perusahaan berada seharusnya diperhatikan.

Tanggung jawab sosial perusahaan juga didasari oleh alasan bahwasanya aktivitas produksi perusahaan membawa dampak kondisi lingkungan dan sosialekonomi masyarakat, khususnya di sekitar perusahaan beroperasi. Selain itu, pemilik perusahaan sejatinya bukan hanya shareholders atau para pemegang saham. Melainkan pula stakeholders, yakni pihak-pihak yang berkepentingan terhadap eksistensi perusahaan. Stakeholders dapat mencakup karyawan dan keluarganya, pelanggan, pemasok, masyarakat sekitar perusahaan, lembaga-lembaga swadaya masyarakat, media massa dan pemerintah selaku regulator. Jenis dan prioritas stakeholders relatif berbeda antara satu perusahaan dengan lainnya, tergantung pada core bisnis perusahaan yang bersangkutan (Supomo, 2004). Sebagai contoh, PT Aneka Tambang, Tbk. dan Rio Tinto menempatkan masyarakat dan lingkungan sekitar sebagai stakeholders dalam skala prioritasnya. Sementara itu, stakeholders dalam skala prioritas bagi produk konsumen seperti Unilever atau Procter \& Gamble adalah para customer-nya.

CSR adalah suatu bentuk prinsip responsibility atau tanggungjawab yang merupakan satu dari empat prinsip Good Corporate Governance (GCG). Tiga prinsip GCG lainnya adalah fairness, transparency, dan accountability. Dalam prinsip responsibility, penekanan yang signifikan diberikan pada kepentingan stakeholders perusahaan. Di sini perusahaan diharuskan memperhatikan kepentingan stakeholders perusahaan, menciptakan nilai tambah (value added) dari produk dan jasa bagi stakeholders perusahaan, dan memelihara kesinambungan nilai tambah yang diciptakannya. Karena itu, prinsip responsibility di sini lebih mencerminkan stakeholders-driven concept (Sita Supomo, Republika, 20 Oktober 2004). Sementara ari sisi perusahaan sendiri, beberapa aspek esensial dari CSR juga sudah dilakukan dengan tingkat yang bervariasi, mulai dari yang paling sederhana seperti donasi hingga kepada yang lebih komprehensif seperti integrasi ke dalam tata cara perusahaan mengoperasikan usahanya (KLH, 2006).

Sekedar mengoverview, sebetulnya dari sisi regulasi dan kelembagaan, pemerintah sudah mengeluarkan sejumlah aturan perundang-undangan mengenai 
standar minimal, khususnya menyangkut kinerja pengelolaan lingkungan oleh perusahaan, yang merupakan tahapan menuju promosi CSR yang lebih terpadu. Inisiatif sukarela yang paling terkenal pada tahun 1990-an adalah PROKASIH (Program Kali Bersih). Program ini diluncurkan pertama kali pada Juni 1989 di delapan provinsi dengan partisipasi 381 perusahaan. Pada tahun 1994, program ini telah berkembang di 13 provinsi dan melibatkan 1.275 perusahaan.

Kemudian pada Juni 1995 pemerintah meluncurkan instrumen Program Penilaian Peringkat Pengelolaan (PROPER) lingkungan. Program ini ditujukan untuk perusahaan yang mekanismenya diumumkan secara rutin kepada masyarakat. Dengan peringkat-peringkat ini perusahaan yang dinilai akan memperoleh insentif maupun disinsentif reputasi, tergantung pada tingkat ketaatannya. Adapun titik tekan aspek penilaian PROPER adalah ketaatan terhadap peraturan pengendalian pencemaran air, pengendalian pencemaran udara, pengelolaan limbah B3, AMDAL serta pengendalian pencemaran laut, dengan sejumlah ketentuan regulasi terkait sebagaimana digambarkan dalam bagan berikut ini.

Di luar aturan-aturan yang terkait dengan penilaian peringkat pengelolaan lingkungan ini, secara terpisah-pisah terdapat berbagai ketentuan yang menjadi legal compliance bagi perusahaan menyangkut aspek-aspek non-lingkungan, seperti sejumlah regulasi tentang ketenagakerjaan, termasuk upah dan keselamatan kerja, dan regulasi tentang perlindungan konsumen. Begitu juga aturan pada masingmasing usaha sektoral juga sudah banyak yang mengatur legal compliance mengenai indikator penilaian kinerja perusahaan, misalnya aturan dari Departemen Kehutanan mengenai evaluasi perusahaan pemegang konsesi HPH dan HTI setiap 3 tahun sekali, atau instrumen pengendalian pertanahan dari BPN untuk mengevaluasi tanah-tanah terlantar pada perusahaan-perusahaan perkebunan pemegang HGU. Sebagai tambahan, beberapa ketentuan perundang-undangan ini juga merupakan daftar yang telah menyediakan kerangka regulasi mengenai legal compliance atas aspek-aspek tertentu dari CSR yang harus dipenuhi oleh perusahaan.

Menurut Gatot Yan. S (2008), secara teoritis CSR dapat didefinisikan sebagai tanggung jawab moral suatu perusahaan terhadap para strategicstakeholders-nya, terutama komunitas atau masyarakat di sekitar wilayah kerja dan operasinya. Parameter keberhasilan suatu perusahaan dalam pandangan CSR adalah mengedepankan prinsip moral dan etis, yakni menggapai suatu hasil terbaik, dengan tidak merugikan kelompok masyarakat lainnya. Perusahaan yang bekerja dengan mengedepankan prinsip moral dan etis akan memberikan manfaat terbesar bagi 
Tantan Hermansah dan Muhtadi Kontribusi Corporate Social Responsibility bagi Penguatan Kohesi Sosial Masyarakat:

Studi Kasus Perusahaan Asing di Bogor

masyarakat. Karena itu, CSR dapat diartikan sebagai komitmen perusahaan untuk mempertanggungjawabkan dampak operasinya dalam dimensi sosial, ekonomi, dan lingkungan, serta terus-menerus menjaga agar dampak tersebut menyumbang manfaat kepada masyarakat dan lingkungan hidupnya.

Lebih dalam lagi, konsep governance melibatkan tidak hanya negara (pemerintah), tetapi juga swasta dan masyarakat sipil. Kesemuanya merupakan aktor yang memiliki peran sama penting dalam penyelenggaraan pemerintahan. Pemerintah, seperti kita ketahui, berperan menciptakan situasi politk dan hukum yang kondusif; swasta berperan dalam menciptakan lapangan pekerjaan dan pendapatan, dan masyarakat sipil berperan dalam menfasilitasi interaksi secara sosial dan politik yang memadai bagi mobilisasi individu atau kelompok-kelompok masyarakat untuk berpartsipasi dalam aktivitas, ekonomi, politik dan sosial.

Dalam konteks demikian, maka gagasan CSR mendapat maknanya karena sektor swasta diharapkan memiliki peran non-ekonomi yang lebih mendalam bagi masyarakat. Jadi paradigma bahwa swasta hanya dapat menghasilkan barang produksi dan mengeruk keuntungan, harus diimbangi sedemikian rupa oleh aktivitas yang berorentasi non bisnis. Termasuk dalam kategori ini adalah tindakan yang menyangkut masyarakat dan lingkungan. Artinya, swasta diharapkan memiliki kontribusi positif bagi proses peningkatan kesejahteraan masyarakat-minimal di sekitarnya.

Adapun modus yang bisa dilakukan antara lain adalah dengan optimalisasi peran CSR dalam satu aksi nyata yang memberdayakan, dalam hal ini gerakan yang disebut sebagai community development (lazim disingkat "CD”), atau pemberdayaan masyarakat. Sebenarnya, CD hanyalah salah satu instrumen untuk melakukan perubahan di masyarakat. Banyak cara lainnya yang dapat dilakukan para agen perubahan (agent of change) dalam melakukan perbaikan kehidupan rakyat Indonesia. Beragam era yang muncul, direspon dengan beragam pendekatan. Di era Orde Baru kita mengenal satu mekanisme perubahan yang didorong oleh negara (baca: pemerintah pusat) melalui program penyuluhan. Penyuluhan adalah program perubahan tata cara bertindak masyarakat melalui bimbingan teknis oleh para ahli kepada masyarakat. Sehingga sering dikatakan bahwa program ini sangat top down.

Dari kelemahan pendekatan tersebut, kemudian muncul pendekatan lain yang lebih kritis, yakni pendekatan pemberdayaan masyarakat. Di era Orde Baru, pendekatan pemberdayaan masyarakat memang kurang populer, meski banyak kepustakaan terbit pada masa ini. Sehingga gerakan pemberdayaan seperti ini 
dilakukan secara terbatas. Sampai era Orde Reformasi tiba, pemberdayaan masyarakat seolah-olah menemukan momentum politiknya. Di mana-mana, didengungkan perlunya pemberdayaan masyarakat. Kelihatannya, gerakan ini bukan semata-mata sebagai kritik atas kegagalan sistem perubahan masyarakat di era Orde Baru, namun lebih jauh mengisi ruang kosong potensi masyarakat untuk melakukan perubahan kehidupannya. Maka jangan heran, hampir di setiap departemen dan instansi, selalu ada institusi pemberdayaan masyarakat.

Pemberdayaan masyarakat yang akhir-akhir ini menjadi sangat tren di berbagai lapisan masyarakat, patut diapresiasi dengan kritis. Sebab tanpa sebuah proses kritik, pemberdayaan masyarakat bisa menjadi pedang bermata dua yang salah-salah menusuk kita sendiri. Sementara itu di sisi lain, substansi masalah belum bisa dipecahkan. Sebagai contoh, nyaris di semua departemen, lembaga swasta (bisnis dan non bisnis) selalu-minimal—menyebut konsep ini sebagai proses yang harus menjadi kewajiban.

Intinya bahwa kepedulian kepada masyarakat yang dilakukan oleh individu atau lembaga sudah memiliki koridor teoritik dan praktik. Bahkan jika kita telisik lebih detail, pakar, praktisi, konseptor, atau kontributor untuk hal ini sudah sangat banyak. Begitu juga dimensi-dimensi pengetahuan yang dikembangkannya. Mulai dari dimensi pemberdayaan ekonomi, sampai kepada politik dan kebudayaan. Bahkan di beberapa kasus, masing-masing dimensi diberikan ruang yang jauh lebih luas dan dalam, sehingga praktik pemberdayaan masyarakat saat ini menjadi sangat kaya.

Menurut Jim Ife dalam "Community Development: Creating Community Alternatives-vision, analysis and practice" (1995), proses pemberdayaan masyarakat harus memiliki prinsip-prinsip yang setidaknya memperhatikan enam masalah berikut: (1) Keterkaitan personal dan politik; (2) Keterkaitan jangka pendek obyektif dengan visi jangka panjang; (3) Keterkaitan antara tatanan lokal dan global; (4) Keterkaitan antara prinsip-prinsip tersebut dan diskusi terkini dari ekologi dan perspektif keadilan sosial; (5) Keterkaitan prinsip yang bermacam-macam; dan (6) Kesalingterkaitan keenam aspek $\mathrm{CD}$ di atas.

Sebagaimana telah disinggung di atas, dalam konteks yang lebih sederhana, CSR bisa merupakan suatu bentuk prinsip responsibility yang menjadi salah satu dari empat prinsip Good Corporate Governance (GCG). Tiga prinsip GCG lainnya adalah fairness, transparency, dan accountability. Dalam prinsip responsibility ini, terdapat penekanan yang signifikan diberikan pada kepentingan stakeholders perusahaan seperti disebutkan di atas. Di sini perusahaan diharuskan 
Tantan Hermansah dan Muhtadi Kontribusi Corporate Social Responsibility bagi Penguatan Kohesi Sosial Masyarakat:

Studi Kasus Perusahaan Asing di Bogor

memperhatikan kepentingan stakeholders perusahaan, menciptakan nilai tambah (value added) dari produk dan jasa bagi stakeholders perusahaan, dan memelihara kesinambungan nilai tambah yang diciptakannya. Karena itu, prinsip responsibility di sini lebih mencerminkan stakeholders-driven concept (Sita Supomo, Republika, 20 Oktober 2004).

Lalu sesuai dengan prinsip corporate citizenship yang mendasari perilaku etis perusahaan, Davernport, (1999) telah mengembangkan 20 komponen dasar yang relevan dengan penerapan CSR secara baik, dan semuanya dapat dikelompokkan lagi ke dalam 8 komponen utama. Komponen-komponen tersebut di antaranya adalah: (1) tingkah laku bisnis etis, meliputi: sifat adil dan jujur, standar kerja tinggi, melatih etis para pimpinan dan eksekutif; (2) komitmen tinggi pada stakeholders, meliputi: keuntungan untuk semua stakeholders, adanya inisiatif dan mewujudkan dialog; (3) peduli masyarakat, meliputi: membangun hubungan timbal balik, dan melibatkan masyarakat dalam operasi perusahaan; (4) terhadap konsumen, meliputi: melindungi hak-haknya, kualitas layanan, dan memberi informasi jujur; (5) terhadap pekerja, meliputi: membangun lingkungan kekeluargaan, tanggung jawab (accountable), upah yang wajar, komunikasi yang luwes, dan mengembangkan pekerja; (6) investasi secara kompetitif; (7) untuk pemasar: berbisnis secara adil; dan (8) komitmen terhadap lingkungan, meliputi: menjaga kualitas lingkungan, dan komitmen terhadap pembangunan berkelanjutan (Jurnal EKOFEUM, 2008).

Dalam konteks yang lebih jauh, penguatan perusahaan melalui aktivitas CSR sebenarnya juga sedang mengkonstruksi apa yang disebut sebagai Good Corporate Governance (GCG). Konsep governance dalam hal ini, sebagaimana dikemukakan oleh Stoker (dalam Kurniawan, 2007) merujuk kepada pengembangan dari gaya memerintah di mana batas-batas antara sektor publik dan sektor swasta menjadi kabur. Pengaburan batas-batas ini sejalan dengan kebutuhan dari negara modern untuk lebih melibatkan mekanisme politik dan pengakuan akan pentingnya isu-isu menyangkut empati dan perasaan dari publik untuk terlibat sehingga memberikan kesempatan bagi adanya mobilisasi baik secara sosial maupun politik.

Dalam konteks demikian, maka gagasan CSR mendapat maknanya karena, sebagaimana dikatakan oleh Malovics, Csigene dan Kraus (Kurniawan, ibid.) sektor swasta diharapkan memiliki peran non-ekonomi yang lebih mendalam bagi masyarakat. Jadi paradigma bahwa swasta hanya dapat menghasilkan barang produksi dan mengeruk keuntungan, harus diimbangi sedemikian rupa oleh aktivitas yang berorentasi non bisnis. Termasuk dalam kategori ini adalah tindakan yang 
menyangkut masyarakat dan lingkungan. Artinya, swasta diharapkan memiliki kontribusi positif bagi proses peningkatan kesejahteraan masyarakat-minimal di sekitarnya.

Sebagai Negara dengan mayoritas penduduk beragama Islam, maka sangat wajar jika perspektif sosiologis-antropologis yang dipergunakan kemudian mengidentifikasi bahwa masyarakat Islam secara logis harus menjadi penerima manfaat yang besar dari program CSR sebuah perusahaan. Jika perusahaan itu berdiri di tengah-tengah kawasan muslim. Dalam konteks pengembangan masyarakat, CSR memang memiliki ruang yang cukup untuk mengejawantahkan nilai-niali tersebut. Hal ini dilihat dari karakter dan sifat dari CSR sendiri yang berangkat dari asumsi relasi yang saling menguntungkan bagi para pihak.

Sayangnya, jika mengacu kepada beberapa studi yang sudah dilakukan sebelumnya, penelitian yang khusus membahas CSR dalam konteks pengembangan masyarakat Islam secara spesifik, belum banyak. Selama ini, riset-riset mengenai aktivitas yang serupa CSR masih di sekitar kedermawanan sosial secara umum saja. Kedermawanan sosial adalah cara pandang yang tidak memperhatikan siapa subyek penerima manfaat. Artinya, kedermawanan bisa dirasakan oleh siapapun yang bersentuhan dengan tindakan tersebut.

Adapun studi yang mengkaji CSR berrelasi dengan pengembangan masyarakat Islam, belum banyak dilakukan. Padahal secara teoritik, relasi antara nilai-nilai Islam dengan kegiatan CSR cukup kuat (Muhammad, 2007). Relasi ini dilihat dari beragam perspektif: mulai dari azas kemanfaatan, sampai kepada nilai spiritual. Jika mengacu kepada gagasan dasar dari CSR, korelasi yang kuat antara misi CSR dengan model kedermawanan dalam nilai-nilai masyarakat Islam, terletak pada dampak sosialnya. Dalam Islam, kewajiban seperti ini bisa antara lain bisa dilihat pada kewajiban sedekah, zakat, hibah, dan hadiah. Semua jenis kewajiban tersebut sangat berkaitan dengan orang lain, yang otomatis karena berhubungan dengan orang atau pihak lain di luar yang berkewajiban, harus ada institusi atau lembaga.

\section{Kontribusi Corporate Social Responsibility Pada Pengembangan Masyarakat}

Jika melihat penjelasan resmi dari perusahaan pelaku CSR, kontribusi kepada pengembangan masyarakat itu bisa dikategorisasi menjadi dua tipologi kelompok masyarakat, yaitu masyarakat umum dan masyarakat Islam. Masyarakat umum adalah mereka yang menerima berbagai macam program dengan tidak membeda-bedakan latar belakang agamanya. Sedangkan masyarakat Islam adalah 
Tantan Hermansah dan Muhtadi Kontribusi Corporate Social Responsibility bagi Penguatan Kohesi Sosial Masyarakat:

Studi Kasus Perusahaan Asing di Bogor

program-program yang diarahkan kepada pengembangan masyarakat Islam. Sedangkan dilihat dari dampak pemberdayaannya, CSR Perusahaan ini bisa dipetakan menjadi dua dimensi, yaitu dampak langsung dan dampak ikutannya. Tetapi sebagaimana temuan studi ini, kedua dampak tersebut ternyata saling berkaitan satu sama lainnya.

Sebenarnya pelembagaan CSR sendiri sebagai praktik Good Corporate Governance tentunya tidak dapat berjalan sendiri. Apalagi sampai terlepas dari lingkungan kelembagaan dan praktik good governance yang lebih luas. Munculnya perilaku "rent seeking" yang demikian sistematis dan meluas, berlanjutnya dan kian mendalamnya praktik korupsi seiring dengan proses desentralisasi, lemahnya penegakan hukum yang melahirkan biaya dan birokrasi administratif tambahan, semua ini menciptakan hambatan eksternal yang menghalangi kalangan bisnis untuk melaksanakan CSR secara menyeluruh.

Berkas-berkas semacam perijinan, ketaatan pada aturan lingkungan, pungutan pajak lokal, dan pengawasan kontrak ketenagakerjaan telah menciptakan regulasi tambahan yang dibuat-buat, dan karenanya menciptakan arena untuk perilaku korupsi dan berburu rente. Hambatan eksternal lainnya mencakup faktorfaktor yang terkait dengan perilaku konsumen dan masyarakat, pengaruh dari organisasi-organisasi civil society, perilaku kalangan politisi, dll. (Deprin: 2008).

Untuk menjadikan CSR sebagai salah satu arena untuk perusahaan membersihkan sistem produksinya, beberapa cara harus berani dilakukan perusahaan antara lain: menerapkan kebijakan internal yang ketat, terutama menyangkut persoalan-persoalan sosio-ekologis yang berkaitan langsung dan tidak langsung dengan perusahaan. Misalnya jika sebuah perusahaan tambang yang beroperasi dan mencemari udara di sekitarnya, maka pihak perusahaan harus memiliki desain yang jelas, nyata, dan riil mengenai penanganan masalah tersebut. Oleh karena itu harus ada pengawasan yang ketat, dengan standard yang sangat ketat, mengenai sistem pengawasan CSR di Indonesia. Apakah setiap bentuk alokasi dana perusahaan tersebut benar-benar dikeluarkan sesuai dengan masalah yang ditimbulkannya atau tidak.

Salah satu yang menarik secara soiologis, sebagian dampak dari sistem produksi perusahan adalah munculnya limbah-limbah produksi. Limbah-limbah ini terjadi karena proses produksi yang menghasilkan produk cacat dan direject. Sebagai contoh limbah yang dihasilkan oleh perusahaan tambang beda dengan limbah industri maufaktur maupun industri agro. Perusahaan tambang mineral umumnya lebih peduli dengan masalah limbah ini. Limbah pertambangan dan 
dampaknya kepada lingkungan juga tergantung kepada bagaimana cara mereka mengelola limbah tersebut. Tailing misalnya, beberapa perusahaan membuangnya ke palung laut dalam yang jaraknya 6,5 KM dari bibir pantai, selain itu, manajemen pengawasan pipa yang sangat ketat dilakukan termasuk audit oleh lembaga independen.

Berbeda dengan perusahaan tambang mineral ini, limbah industri manufaktur tidak selamanya sebagai limbah yang dibuang. Contoh di perusahaan pelaku CSR yang memproduksi ban ini. Limbah sisa produksi, maupaun produk yang reject (cacat), justru bisa dimaknai secara berbeda. Limbah pabrik di sekitar perusahaan bermacam-macam. Salah satu yang paling besar adalah limbah hasil cacat produksi. Proses pengelolaan limbah di masyarakat sekitar perusahaan adalah sebagai berikut:

"Mungkin tadinya tidak ada yang membayangkan bahwa barang cacat bisa bernilai ekonomi. Bahkan karena di awal-awal perusahaan berdiri sampai generasi kedua dan ketiga karyawan perusahaan yang berdomisili di sekitar pabrik itu masih mengandalkan model konvensional yakni sebagai karyawan perusahaan, maka masyarakat menganggap bahwa dengan bekerja mengikuti jadual saja sudah cukup. Tidak ada yang terpikir untuk memanfaatkan apa yang ada di pabrik itu sebagai bagian dari kegiatan ekonomi.

Baru ketika krisis ekonomi tahun 98 melanda. Tidak terkecuali masyarakat di sekitar pabrik. Mereka yang mengandalkan penghasilan dari warungwarung makan serta kos-kosan mengalami penurunan omset sehubungan dengan rasionalisasi perusahaan. Tetapi justru ketika situasi meredup itu, peluang lain terbuka, meski tidak semua mampu menangkapnya.

Mahalnya barang-barang manufaktur yang selama ini berbasis impor menyebabkan banyak pelaku industri mengandalkan barang daur ulang untuk menopang kebutuhan produksinya. Salah satunya adalah kebutuhan karet. Seperti kita ketahui bahwa karet adalah benda yang sudah menjadi kebutuhan banyak industri. Di sisi lain karet bisa dibentuk dari bahan baku daur ulang, salah satunya adalah bahan dari produk ban yang cacat produksi yang dinamai "Falet". Falet adalah produk ban yang gagal baik karena salah "adonan” atau kesalahan lainnya. Selama ini produk ini dibuang begitu saja, karena tidak ada masyarakat yang bisa mengelolanya. Sampai akhirnya ada salah seorang mantan karyawan yang mencoba memisahkah benang dan besinya dari falet tersebut dengan cara "dijugil" 
Tantan Hermansah dan Muhtadi

Kontribusi Corporate Social Responsibility bagi Penguatan Kohesi Sosial Masyarakat:

Studi Kasus Perusahaan Asing di Bogor

lalu "disosot". Menjugil dan menyosot adalah proses mengeluarkan benang-benang dan benda lain non karet dari sebuah produk karet (bahasa industrinya Crum Rubber) tersebut. Sehingga setelah disosot tersebut, karet-karet itu bisa dijadikan produk karet lain. Setelah karet bersih dari benda-benda asing tersebut, tahap berikutnya adala mengolahnya kembali dengan racikan kimia tertentu yang akhirnya menghasilkan karet balok. Karet-karet balok inilah yang sangat disukai oleh para pedagang untuk kembali dimasukkan ke pabrik manufaktur lain sebagai bahan untuk menunjang kabutuhan produk berbasis karet.

Saat ini, pengelolaan limbah sudah menjadi kegiatan ekonomi tersendiri. Mulai dari yang skalanya rumah tangga sampai kepada yang berbasis perusahaan. Bahkan beberapa pemain non-lokal (artinya dari luar Bogor) sudah mulai ikutan. Terlebih lagi mereka mampu melakukan lobi kepada "orang dalam" sehingga bisa memegang semacam kontrak angkut limbah tersebut."

Penelitian ini menemukan bahwa masalah limbah ini demikian signifikan sebagai perekat sosial masyarakat. Sebab banyak dari warga sekitar yang akhirnya cukup kaya dengan adanya kegiatan industri limbah ini. Contoh Pak Sofyan. Dengan kemampuannya untuk menyediakan mesin pengolah karet-karet yang sudah bersih dan siap diracik tersebut, ia bisa hidup cukup makmur. Apalagi tidak semua orang bisa berinvestasi pada usaha model dia.

Dilihat dari sisi ekonomi, kegiatan di atas memang sangat menguntungkan serta mampu memberikan kontribusi pada masyarakat. Hal ini juga yang menjawab pertanyaan mendasar dari studi ini, bahwa apa yang menjadi variable sosiologis sehingga perusahaan ini sangat minim gejolak. Akan tetapi karena berbagai dampak tersebut lebih bersifat top down, maksudnya karena terjadi sebagai dampak ikutan dari adanya perusahaan, sebenarnya manfaat dari kegiatan CSR yang langsung pada kegiatan community development itu ada tapi "terasa biasa saja". Kegiatan yang dilakukan perusahaan seperti membantu sarana ibadah, santunan, dan sebagainyahanya malah menciptakan ketegantungan kepada perusahaan.

Relasi yang menyebabkan ketergantungan jelas bertentangan dengan agenda dan kepentingan CSR sendiri. Sebab sejatinya CSR harus memandirikan warga di sekitar area, selain tentu saja menjamin keberlanjutan ekologi. Cara pengolahan limbah yang dilakukan perusahaan memang memperlihatkan komitmen yang berbeda-beda antar perusahaan. Perusahaan yang komitmen kepada 
lingkungannya tinggi, menerapkan standar yang sangat kuat untuk mengawasi persoalan limbah ini.

Dampak sosiologis dengan kehadiran perusahaan sekelas perusahaan pelaku CSR ini jelas sangat banyak. Terutama munculnya bara konflik-kontestatif yang bersifat laten. Munculnya konflik ini antara lain bisa dilihat dalam beberapa symptom berikut:

1. Kompetisi dengan Pendatang

Kompetisi dengan pendatang terjadi dalam beberapa sesi. Misalnya ketika tahap pembangunan dan pengembangan infrastruktur dilakukan-yang ini sudah terjadi lebih dulu. Tetapi saat ini warga lokal yang jumlah maupun kapasitasnya terbatas jelas tidak bisa dijadikan andalan oleh perusahaan. Sehingga warga pendatang didatangkannya. Dari sekian banyak warga pendatang itu, beberapa di antara mereka sudah profesional sehingga terjadi jum up yang cukup jauh dengan warga setempat. Kemudian pada tahap berikutnya ketika perusahaan semakin berkembang dan perekonomian pun semakin melaju pesat, warga lokal berhadapan dengan pendatang dalam kemampuan menciptakan atau memanfaatkan peluang yang untuk kesejahteraan hidupnya. Sehingga pada tahap ini terjadi apa yang disebut sebagai "jati eleh ku junti" atau tanaman asli kalah dengan tanaman liar/ pendatang. Hal ini terbukti para pemain limbah sudah ada yang mulai datang dari daerah lain — bukan Urang Bogor lagi.

\section{Sistem dan Pola Produksi}

Jelas sekali kehadiran perusahaan telah menyebabkan munculnya sistem produksi baru pada warga Bogor. Sistem produksi baru ini bisa ditemukan pada beberapa keadaan berikut: (a) masyarakat dihadapkan pada masuknya berbagai sistem atau tatacara yang baru dalam meningkatkan kesejahteraan kehidupan. Misalnya dari budaya malas ke budaya disiplin! (b) Masyarakat dihadapkan pada masuknya berbagai teknologi yang menjadi dampak ikutan dari kehadiran industri. Teknologi baru yang hadir umumnya belum bisa dikuasai oleh warga lokal. Jika pun mereka bisa menguasainya, memerlukan proses yang lama dan itu pun masih tetap dalam skala seleksi alam.

3. Harga Kebutuhan Pokok Sehari-hari

Dampak sosial ekonomi yang pasti di area perusahaan meningkatnya pendapatan penduduk di sekitar kawasan. Dengan terjadinya peningkatan pendapatan ini otomatis terjadi distribusi penguasaan atas beberapa komoditas utama, maupun terjadi peningkatan permintaan. Sementara itu, tidak semua permintaan bisa dipenuhi segera. Dalam konteks seperti itu, hukum ekonomi 
Tantan Hermansah dan Muhtadi Kontribusi Corporate Social Responsibility bagi Penguatan Kohesi Sosial Masyarakat:

Studi Kasus Perusahaan Asing di Bogor

bekerja dan sebuah barang bisa menjadi mahal. Keadaan lain yang menyebabkan harga mahal bukan melulu dari sisi penawaran, namun justru dari perilaku pemilik barang. Misalnya pada sebua daerah di mana ada sebuah perusahaan tambang yang sedang beroperasi, harga yang mahal diakibatkan oleh perilaku pemilik barang yang ingin dibeli dengan harga lebih dari kebiasaan, dengan alasan yang membeli adalah pekerja tambang.

\section{Corporate Social Responsibility bagi Pengembangan Masyarakat Islam (?)}

Sebagai negara dengan jumlah penduduk Muslim terbesar, pertanyaan bagaimana kontribusi CSR bagi pengembangan masyarakat Islam layak diajukan. Beberapa argumentasi yang mendukung statemen ini antara lain: pertama, pada kebanyakan daerah tempat perusahaan besar yang terkena kewajiban melaksanakan CSR beroperasi, dipastikan ada kaum Muslim di situ. Bahkan ummat Islam tidak hanya merupakan penduduk yang sudah eksisting, tetapi juga bagian dari sistem produksi perusahaan. Sehingga kemelekatan antara perusahaan dengan kaum muslim tidak bisa ditolak; kedua, perusahaan pelaku CSR ini ada di pulau Jawa, pada provinsi Jawa Barat yang mayoritas berpenduduk Muslim. Bahkan lokasi tempat perusahaan beroperasi pun merupakan kawasan padat tempat kaum muslimin tinggal; ketiga, dinamika sosial-budaya pada masyarakat Islam, sekecil apapun akan memiliki dampak pada kehidupan sosial sekitarnya. Hal ini terjadi karena selain masyarakat Islam adalah mayoritas, namun juga terkait dengan nadi kehidupan masyarakat itu sendiri.

Kembali ke pertanyaan awal bab ini dan juga pertanyaan studi ini, bagaimana kontribusi CSR bagi masyarakat Islam sekitar perusahaan?

Dari fakta dan hasil refleksi peneliti di atas jelas sekali bahwa CSR di perusahaan tidak memberikan kontribusi khusus kepada pengembangan masyarakat Islam sekitar perusahaan. Hal ini bisa dilihat pada beberapa temuan lapangan berikut:

1. Adanya beragam bantuan sosial ke masjid-masjid, PAUD, maupun santunan bagi anak yatim yang rutin, bisa dinilai tidak sebagai bagian dari kontribusi spesial perusahaan. Bahkan jika ditelisik lebih jauh, berbagai bantuan dikeluarkan kepada lembaga-lembaga seperti di atas, dikarenakan lebih kepada aspek strategis dari perusahaan sendiri. Di mana subyek anggota dari setiap lembaga Islam dipastikan cukup banyak, sehingga akan mempermudah klaim dari perusahaan dalam mempublikasikan aspek penerima manfaat dari CSR yang mereka keluarkan; 
2. Jika memang perusahaan "berniat" untuk memberikan peran kepada penguatan dan pemberdayaan masyarakat Islam, sejatinya langkah-langkah berikut yang mesti dijalankan oleh perusahaan dalam mengelola CSR. Pertama, identifikasi kebutuhan. Perusahaan harus melakukan social mapping kebutuhan riil masyarakat yang terkena dampak operasi. Sehingga bantuan dan jenisnya bisa lebih tepat sasaran; Kedua, melakukan proses pengelolaan secara partitipatif. Perusahaan harus berkolaborasi dengan para pegiat kemasyarakatan untuk mengelola sumberdaya CSR ini menjadi lebih produktif; Ketiga, menjadikan program terkait masyarakat Islam sebagai prioritas. Tanpa bermaksud diskriminatif, maka perusahaan harus menjadikan kaum Muslimin sebagai target utama kegiatan CSR dengan membuat roadmap secara partisipatif; Keempat, membuat target capaian kegiatan dengan sistematis dan strukturatif. Selama ini yang dilakukan perusahaan baru pada level meredam gejolak sosial saja.

\section{Corporate Social Responsibility dan Kohesi Sosial}

Salah satu ancaman kehadiran sebuah perusahaan di tengah-tengah warga adalah munculnnya gejolak sosial yang kemudian bisa mengganggu sistem produksi. Agaknya perusahaan pelaku CSR ini sangat menyadari kondisi demikian, sehingga sejak awal berdiri, mereka melibatkan orang setempat sebagai bagian dari para pekerjanya. Dengan metode seperti ini, maka kemudian ada rasa 'ketergantungan' dari para pekerja yang kemudian berbuah kepercayaan.

Kepercayaan merupakan dasar dari menguatnya hubungan sosial. Para pihak yang sudah saling percaya umumnya bisa saling menjaga, meski secara riil tidak menjadi bagian dari pengambil kebijakan. Namun demikian, karena di dalamnya ada simbiosa-mutualisme, maka hubungan-hubungan ini kemudian menciptakan ruang yang bagi perusahaan, menjamin keberlangsungan.

Jika ditelaah lebih jauh, apakah terciptanya kohesi sosial antara perusahaan dengan masyarakat tersebut akibat dari program CSR. Studi ini menemukannya tidak demikian. Ada beberapa penjelasan mengenai kesimpulan ini, yaitu:

1. Dibandingkan dengan aturan atau regulasi CSR baik di Indonesia maupun dunia, hadirnya perusahaan ini di Kota Bogor jauh lebih lama. Artinya, tidak mungkin perusahaan melakukan suatu kebijakan yang aturannya belum ada. Oleh karena persoalan kohesi sosial ini penting bagi perusahaan sejak awal perusahaan berdiri, mereka sudah memproyeksikan akan partisipasi dan 
Tantan Hermansah dan Muhtadi Kontribusi Corporate Social Responsibility bagi Penguatan Kohesi Sosial Masyarakat:

Studi Kasus Perusahaan Asing di Bogor

keterlibatan warga setempat dalam perusahaan sendiri-bukan dalam kegiatan CSR;

2. CSR mengandung program yang khas dan jelas acuannya. Kekakuan ini jelas bukan merupakan garansi bagi perusahaan dalam mempertahankan keberlangsungan usahanya. Apalagi perusahaan ini sangat berkaitan dengan sumberdaya alam (hutan karet) yang secara riil melibatkan banyak warga dan para pihak. Tanpa pendekatan yang tepat, terarah, dan fokus, maka bisa dipastikan perusahaan akan terancam;

3. Variabel kohesi sosial adalah kepercayaan. Selain kepercayaannya, juga melekat pada unsur waktu. Ketika ada huru hara 1998 yang melibatkan banyak pihak dan mengancam orang asing, perusahaan pelaku CSR di Kota Bogor ini seperti nyaris tidak tersentuh. Menurut pengakuan warga, karena d dalam perusahaan tersebut ada "orang-orang sini", maka yang terjadi justru mereka ikut menjaga perusahaan tersebut dari sikap brutal warga.

\section{Kesimpulan}

Studi ini didasarkan pada keingintahuan dari peneliti mengenai implementasi dari UU No. 25 Tahun 2007 tentang penanaman modal, dan UU No 40 Tahun 2007 tentang Perseroan terbatas yang didalamnya mengamanatkan kepada perusahaan untuk melakukan Tanggung Jawab Sosial Lingkungan (TJSL). Cara melihatnya dengan melihat di tingkat masyarakat.

Hasil studi ini menemukan bahwa jauh sebelum CSR menjadi ranah mandatory berbasis regulasi yang setara Undang-undang, ada perusahaan yang mampu menjalin relasi sosial dengan baik kepada masyarakat sekitar, yang ternyata bisa berkelanjutan. Berkelanjutan dimaknai dalam dua dimensi yakni dari sisi keberlanjutan organisasi perusahaan dan juga kerekatannya dengan masyarakat sekitar. Sehingga perusahaan tidak mendapatkan dampak eksternalitas negatif yang menyita energi.

Perusahaan pelaku CSR ini menerapkan prinsip-prinsip TJSL dalam bentuk yang bervariasi kepada masyarakat. Ternyata jika dinamika masyarakat sebagai tolok ukur dari keberhasilan perusahaan, maka sebenarnya tipikal perusahaan seperti ini, tanpa ada amanah CSR pun memiliki kapasitas yang cukup dalam mengelola TJSL ini.

Sedangkan yang berikutnya, studi ini ingin melihat bagaimana kontribusi ini lebih spesifik kepada masyarakat Islam. Seperti dijelaskan cukup panjang pada isi, bahwa pemaknaan Islam secara sosiologis dalam studi ini memberikan arti 
bahwa kontribusinya bisa dikatakan. Meski jika dilihat lebih rinci dengan melibatkan organisasi Islam, ternyata kontribusinya biasa saja. Dengan demikian, maka tergantung kita melihat dari sisi yang mana. Tetapi studi ini menyimpulkan bahwa kontribusi CSR dalam arti TJSL dari perusahaan kepada masyarakat Islam itu ada, meski belum sebesar yang diimajinasikan penerimanya.

Oleh karena itu studi ini memberikan beberapa rekomendasi:

1. CSR jika memang dimaksudkan sebagai mandatory yang mengikat perusahaan, maka Negara harus membuat aturan teknis yang lebih detil dan lengkap, termasuk sasaran dan targetnya. Sebab jika tidak ada aturan teknisnya, maka perusahaan bisa berimprovisasi seenaknya. Hadirnya PP No 47 Tahun 2012 tentang Tanggung Jawab Sosial dan Lingkungan di Perseroan Terbatas, diakui belum bisa menjangkau produk praktis dari CSR tersebut. Sebab PP tersebut lebih mengatur persoalan keorganisasian penyelenggara TJSL tersebut.

2. CSR di Indonesia harus diarahkan memiliki manfaat langsung dan berkelanjutan bagi masyarakat setempat/ lokal. Inilah CSR yang memberdayakan, sebab dalam praktiknya bukan kegiatan karitatfi yang sifatnya hanya menjadi gula-gula bagi masyarakat sekitar saja. Jika kebutuhan untuk keberlanjutan, maka desain CSR harus jelas. Sehingga sistem evaluasi dan monitoringnya pun bisa terukur dan terarah. 
Tantan Hermansah dan Muhtadi Kontribusi Corporate Social Responsibility bagi Penguatan Kohesi Sosial Masyarakat:

Studi Kasus Perusahaan Asing di Bogor

\section{Daftar Pustaka}

Achda, B. Tamam. 2006. Konteks Sosiologis Perkembangan Corporate Social Responsibility (CSR) dan Implementasinya di Indonesia. Paper dipresentasikan di Jakarta, 23 Agustus 2006.

Adi, Rukminto. Pemberdayaan, Pengembangan Masyarakat dan Intervensi Komuitas, Pengantar pada pemikiran dan Pendekatan Praktis. Paper

Agusta, Ivanovich. 2010. CSR dan Pemberdayaan Masyarakat. Paper dipresentasikan di Jakarta, 2010.

Andriof, J. Et al. 2001. Perspectives on Corporate Citixenship. Mc Kintosh. NY

Badriadi, Lili, dkk. 2005. Zakat dan Wirausaha. Jakarta: CV Pustaka Amri.

Collier, dkk., 1996. Pendekatan Baru dalam Pembangunan Perdesaan di Jawa: kajian Perdesaan Selama Duapuluh Lima Tahun. Jakarta: YOI.

Cruz, Jose M.. 2007. Dynamics of Supply Chain Networks with Corporate Social Responsibility (CSR) through Integrated Environmental Decision-making. Department of Operations and Information Management. School of Business, University of Connecticut at Storrs.

Deputi Bidang Pengelolaan B3 dan Limbah B3 Kementerian Lingkungan Hidup. 2006. Proper Sebagai Instrumen Pengukuran Penerapan Csr Oleh Perusahaan. Paper dipresentasikan di Jakarta, 23 Agustus 2006.

Fakih, Farid. 2000. "Tinjuan Kritis dalam Revolusi Hijau”, dalam 'Meggeser Pembangunan Memperkuat Rakyat’. Lapera: Yogyakarta.

Fauzi, Noer. 1999. Petani dan Penguasa: DInamika Perjalanan Politik Agraria di Indonesia. Insist, KPA, Pustaka Pelajar: Yogyakarta.

Hikmat, R. Harry. 2004. Strategi Pemberdayaan Masyarakat. Bandung: Humaniora Utama Press.

Hopkins, Michael. 2007. Corporate Social Responsibility and International Development Is Business the Solution? Penerbit Earthscan, 2007.

http//www.bappenas.com/naskah no. 20 juni-juli 2000/ Friedmann (1992):

Empowement: the Politics of Alternative Development. Cambridge Mass: Blackwell Publisher. Page 4

http// www.munindo.brd.de."

http://ekbis.sindonews.com/read/2013/06/24/34/753575/ini-27-perusahaan-peraihcsr-award-koran-sindo-2013

http://soeharto.co/prestasi-pembangunan-bidang-ekonomi

http://www.depdiknas.go.id/Jurnal/32/pendidikan_pola_pemberdayaan masyarakat http://www.goodyear-indonesia.com/about/history.asp 
Ife. Jim. 1995. Community Development: Creating Community Alternativesvision, analysis and practice.

Kemp, Melody. 2001. Corporate Social Responsibility in Indonesia Quixotic Dream or Confident Expectation? United Nations Research Institute for Social Development, 2001

Mohammad, Javed. 2007. Corporate Socil Responsibility in Islam. PhD Dissertation, 2007. Auckland University, New Zealand

Rika. 2010. Corporate Social, Rresponsibility PT Aetra Air Jakarta. Paper yang dipresentasikan di Jakarta 29 November 2010.

Siregar, Chairil N.. 2007. Analisis Sosiologis Terhadap Implementasi Corporate Social Responsibility dalam Masyarakat Indonesia. Jurnal Sosioteknologi Edisi 12 Tahun 6, Desember 2007.

Suharto, Edi. 2005. Membangun Masyarakat Memberdayakan Rakyat. Bandung: PT Refika Aditama.

Sumadiningrat, Gunawan. 1997. Pembangunan Daerah dan Pemberdayaan Masyarakat. Jakarta: Bina Rena Pariwara.

Tjondronegoro, Sediono M.P. dan Gunawa Wiradi. Dua Abad Penguasaan Tanah: Pola Penguasaan Pertanian di Jawa dari Masa ke Masa. Jakarta Gramedia: 1984.

Undang Undang Republik Indonesia Nomor 25 Tahun 2007 Tentang Penanaman Modal

Undang-Undang Republik Indonesia Nomor 40 Tahun 2007 Tentang Perseroan Terbatas

Wiradi, Gunawan. 2000. Tonggak-tonggak Perjalanan Kebijaksanaan Agraria di Indonesia.

Zubaidi. 2007. Wacana Pembangunan Alternatif. Jogjakarta: Ar-Ruzz. 
Tantan Hermansah dan Muhtadi Kontribusi Corporate Social Responsibility bagi Penguatan Kohesi Sosial Masyarakat: Studi Kasus Perusahaan Asing di Bogor

Intizar, Volume 23, Nomor 1, 2017 